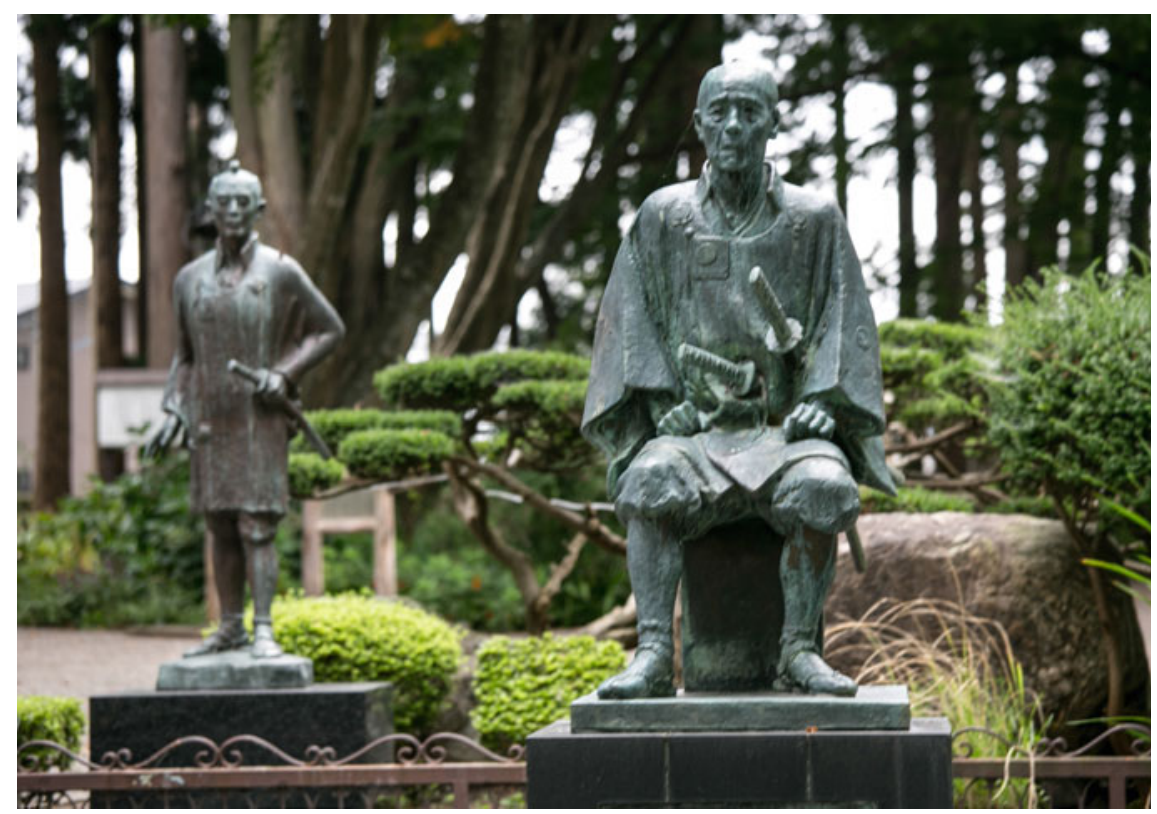

Statue of Tsuto Nitobe in Taiso Jinja in Towada city with his son Jujiro Nitobe's in the back. Source Photographed by Yoshiyuki Kudo, published in Towadashi Shiseki Bunkazai map, Towada city Cultural Heritage Preservation Committee, June 2016 


\title{
Chapter 8 \\ Archaic Water: The Role of a Legend in Constructing the Water Management Heritage of Sanbonkihara, Japan
}

\author{
Izumi Kuroishi
}

\begin{abstract}
Until the end of the nineteenth century, agriculture formed the basis of cultural identity in the many parts of Japan where land and water were locally maintained, managed, and sustained (Wigen 1995; Toyama 1993). This chapter expands the Japanese idea of heritage beyond the question of beauty to include agricultural social systems and water management, exploring the long-term interactive relationship between water resources, the riverine landscape, and local people (Soja 2003). It does so by unraveling the formation and transformation of the legend of the irrigation pioneers. Tsutō Nitobe, a samurai of the Nanbu clan, is legendary for his pioneering water resource management and land reclamation in Japan's Sanbonkihara region in the nineteenth century (Ministry of Agriculture, Forestry and Fisheries 2018). After his death, his irrigation project was the pride of the region; part of the legend is that subsequent irrigation projects inherited the spirit of his work (Northeast Agricultural Administration Bureau 2018). The legend changed over time: the Meiji government and postwar governmental officials developed the nation in Nitobe's name; and today Land Improvement Districts (LID), or water user associations, and agricultural bureaus exalt Nitobe as the spiritual symbol of agricultural society and its cultural landscapes. However, in on-site research, we discovered that many untold people put together these projects. This chapter shows that the tangible heritage of the irrigation project is inseparable from the area's historical identity or intangible heritage.
\end{abstract}

Keywords Inaoi River · Irrigation · Land reclamation · Legend · Tangible heritage $\cdot$ Japanese modernization

\footnotetext{
I. Kuroishi $(\bowtie)$

Aoyama Gakuin University, Tokyo, Japan

e-mail: izumi-k@sccs.aoyama.ac.jp

(C) The Author(s) 2020

C. Hein (ed.), Adaptive Strategies for Water Heritage, https://doi.org/10.1007/978-3-030-00268-8_8
} 


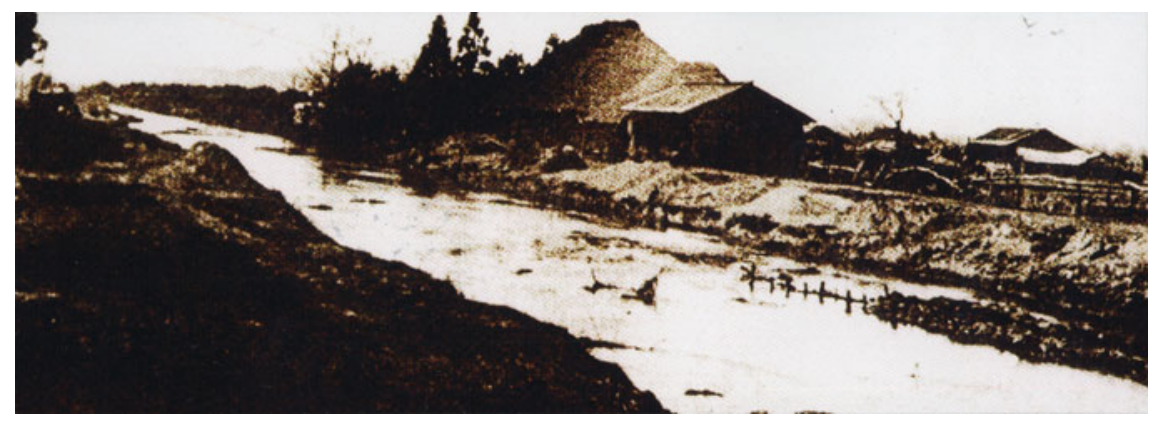

Fig. 1 The photo of Inaoi River landscape at the beginning of Meiji period showing Nitobe's huge scale in old agricultural landscape. Source History of Land Improvement Project of Inaoi River, 2010; released under a Creative Commons Attribution-Non Commercial-No Derivatives 4.0 International License

\section{Introduction}

Legends circulating throughout Asia describe water as sacred and highlight its importance in sustaining life. Although this chapter will not examine mythological understandings of water in Japan, we hold that it is nonetheless important to recognize the close relationship between mythology, historical legend, and tangible water heritage (Bruner 2003) and examine how legends and personal narratives about water have been kept alive and allowed to thrive in the face of political and economic restructuring. In particular, we unravel the formation and transformation of the legend of Tsutō Nitobe. A samurai of the Nanbu clan, Nitobe is legendary for his pioneering water resource management and land reclamation in Sanbonkihara in the nineteenth century . He created the first intake from the Oirase River to create Inaoi River, which later connected the Oirase Valley and Towada Lake to the Pacific Ocean. Oirase Valley and Sanbonkihara are now listed as Japanese water landscape heritage structures. However, in on-site research, we discovered that the legend changed over time, and in parallel to the change in the story of Nitobe the significance of water in this region also shifted, from an agricultural resource to a treasured physical and symbolic element in the national landscape. Historians have consistently excluded other actors and dynamics to create the symbolic images of Nitobe (Fig. 1).

\section{The History of Water Management Systems and Society in Japan}

Before discussing the role played by Nitobe in greater detail, it is necessary to convey the history of Japanese agricultural water systems, to illustrate the ways in which the community system and legal systems of water management (particularly that of 
agricultural paddy field water) are intertwined and form the community's values. This work frames the memories and legendary stories of the ancestor Nitobe-an intangible heritage-which, in turn, helps to create the communal meaning of cultural identity, as it is inscribed in the tangible heritage of land reclamation (Anderson 1983).

Ingenious political systems integrated water management within the village community system from the Edo period until after World War II (Kimura 2010; Komori 1996; Yamasaki, ed. by Ishii et al. 1996). In the Edo period (1603-1867), new laws and policies shaped the relationship between the water right, ownership of land, the village community system, and taxation. The Tokugawa government formed the water management association of villages in each region to organize irrigation-in effect, to ensure the collective operation and maintenance of water facilities as well as to regulate both water rights and distribution systems in each village (Akimoto 2004). As a result, both land and water were managed and owned by all village residents and agricultural works and environmental management became an everyday matter in village governance.

The government regulated the water right much as it had earlier regulated river systems (Ishii et al. 1996). In the Meiji period, all water and land with no clear ownership belonged to the government: they were made public resources. In 1896, the Meiji government established the River Law under which the national government decided every issue pertaining to rivers. In 1898, the Meiji Civil Code approved the organized water right system of the Edo period as customary law and established a rule to prioritize the older, local water right over the newer national one (Okuda 2010; Yamasaki 1996). In 1909, the government revised regulations for the improvement of the drainage system; and in 1923, it started to improve the main drainage network and to invest heavily in land improvement projects to modernize the agricultural water right system (Miyazaki 2009).

In 1949, the Land Improvement Law extended pre-war water management systems into the postwar agricultural reform. The law formed Land Improvement Districts or water user associations. The LIDs then maintained and organized water systems and coordinated water management with individual landowners. They improved and managed agricultural water facilities that supply and drain water; improved agricultural land infrastructure, such as underground drainage; created landmarks, agricultural land, and grasslands; constructed farm roads; repaired irrigation ponds and installed disaster prevention devices to agricultural land; and managed rivers that served as resources for farming and consumption, as well as surrounding landscapes that contained sewers and roads (Shobayashi et al. 2017; Ministry of Agriculture, Forestry and Fisheries Production 2017). Later, with the advent of industrialization of water use and cities' growing demand for water, the government (in 1964) revised the River Law, such that, while they respected the customary water right, public institutions controlled the water supply. So, then, government sustained both the LID's and customary law, in order to stabilize the economic and social structure of the nation as well as to codify the water environment during this period of modernization of Japanese society (Kide 1984). 


\section{Review of Existing Studies}

Intangible heritage, memories, and the history of water resource management are in fact connected to the tangible heritage of the Japanese water landscape. While agricultural scholars, ethnographers, historians, and geographers have analyzed how the social management system formed agricultural society and have examined historical figures and narratives, they have not extended their studies to landscape and heritage (Yanagita 1997; Nitobe 1898). Landscape heritage study in Japan was founded on the idea of identifying beautiful and characteristic historical landscapes for tourism (Shiga 1995). And these scholars did not move beyond these bounds to critically examine the tripartite relationship between spatiality, sociality, and historicity (Watsuji 1979; Higuchi 1975). To provide some context, until the end of the 1960s, Japanese regional and urban planning studies emphasized effective planning to modernize rural areas from an engineering viewpoint (Ishida 2004). It was in the 1980s that urban studies scholars began to study the water environment in Japan, joining architectural scholars (Kawahara 2001). And although Japan established a chapter of ICOMOS, the international NGO which protects heritage in 1972, it did not become a party of the UNESCO World Heritage Convention until 1992, as the national government could not promise to protect historical monuments and sites as public values until then.

Heritage historians like Emma Waterson and Laurajane Smith have addressed the difficulty of integrating social history into discussions of tangible heritage. They argue that definitions of heritage often contain idealized conceptions of community that perpetuate constructions of "others" which the heritage process then institutionalizes (Waterson and Smith 2010). For example, studies of historical and agricultural social life have often constructed nationalist and romantic images of rural areas, which the tourism industry then uses in its advertising campaigns. The modernization of rural Sanbonkihara and the stories of that modernization help us think about constructions of community and heritage, and explore the interrelationship of agricultural water systems with local landscapes and local histories.

\section{General History of Sanbonkihara's Reclamation Developments}

Sanbonkihara was long a barren land filled with the volcanic ash and gravel left behind by the eruption of Mt. Hakkoda a million years before and the formation of the Towada Lake caldera. The Sanbonkihara plateau is in the east of the northern part of the main Japanese island of Honshu and includes many municipalities (Towada City, Rokunohe Town, Shimoda Town, Hyakkoko Town, Misawa City, Towada Lake Town, Shichinohe Town, and Kamikita Town). The area measures twenty-seven kilometers from east to west and eight kilometers from north to south. The substantial difference in elevation - of more than thirty meters-between the Sanbonkihara plateau and 
the Oirase River, coupled with poor water retention capacity of the soil, made the plateau difficult to irrigate and thus unsuitable for rice cultivation. Sanbonkihara is furthermore susceptible to cold winds in the summer. Inhabitants often suffer famine. Farmers on the plateau planted field crops, like millet and soybeans, and reared horses as agricultural activity. These difficult conditions have made Sanbonkihara one of Japan's three major historical cultivation regions that have overcome natural difficulties to achieve agricultural productivity (the other two are Kawaminami cho of Miyazaki prefecture and Yabuki cho of Fukushima prefecture) (Fig. 2).

From the seventeenth century, small scale primitive hydrophobic developments utilizing natural terrain were constructed between several villages in Sanbonki area and Oirase River (Fig. 3). In 1853, Tsutō Nitobe gathered sixty-five comrades to initiate a first massive irrigation project in Sanbonkihara. They dug a six thousand meter tunnel through the Tengumori and Sakura mountains to take water up from the Oirase River through a water weir. This newly created conduit, the Inaoi River, reached approximately $10.3 \mathrm{~km}$ in length, boasting three hundred hectares of paddy fields cultivated in its basin in 1859. In 1861, Tsutō's son Jujiro took over the work to expand the clan's territory, having studied various industries around Japan and proposed a plan to extend the Inaoi River to Ogawara Lake close to the Pacific Ocean. Following his son's tragic death in 1867, Tsutō persisted in realizing the project and completed $1.1 \mathrm{~km}$ of the second conduit. Unfortunately, following the Meiji restoration in 1868, funding for new paddy irrigation-provided by the Nanbu clan-ceased and the project was shelved, relegating Sanbonkihara to ruin (Aomori Kenshi Hensan Kingendaibukai, v6 2015).

Approximately fifteen years later, in the Meiji period, the Inaoi River irrigation project was revived and received renewed support from the state. With the help of the Japanese government in 1884, Shigeaki Fujita established the Kyoritsu Reclamation Company, restored the old conduits constructed by the Nitobe family, and resumed reclamation of Sanbonkihara. In 1888, Eiichi Shibusawa, an industrialist who is widely recognized as the father of Japanese capitalism and friend to Nitobe, bought out the Kyoritsu Reclamation Company, opening the seventeen-hundred and one-hectare Shibusawa farm in Sanbonkihara (Sanbonkihara Kaihatsu Kenkyukai 1967; Ogasawara 1994; Mizuno 1961). The Inaoi River had been lengthened tremendously, to 39 km, reaching the Pacific Ocean by 1897. In 1905, Kyoritsu Reclamation Company became a stock-issuing company named the Sanbonki Reclamation Corporation, an event which signaled a marked growth in the scale of the irrigation project. The agricultural bureaucrat and scholar Saburo Mizoguchi (1948), reflecting on these events from his post-World War II perspective, explained these later Meiji period projects as the successors to Nitobe's endeavors (Fig. 4).

In 1920, Noriyoshi Mizuno, both an agricultural engineer and a pupil of Shibusawa, took office as the manager of the Shibusawa farm and worked to transfer its water management to the government (Ogasawara 1996). Following Mizuno's proposals to the government, in 1937, the Tohoku Promotion Research Council selected the Sanbonkihara district as a development area. It then set into motion a large-scale Sanbonkihara national reclamation project that lasted from 1938 to 1944, with several administrative bodies regulating the movement of water from Lake Towada to 


\section{三本木眺望之図}

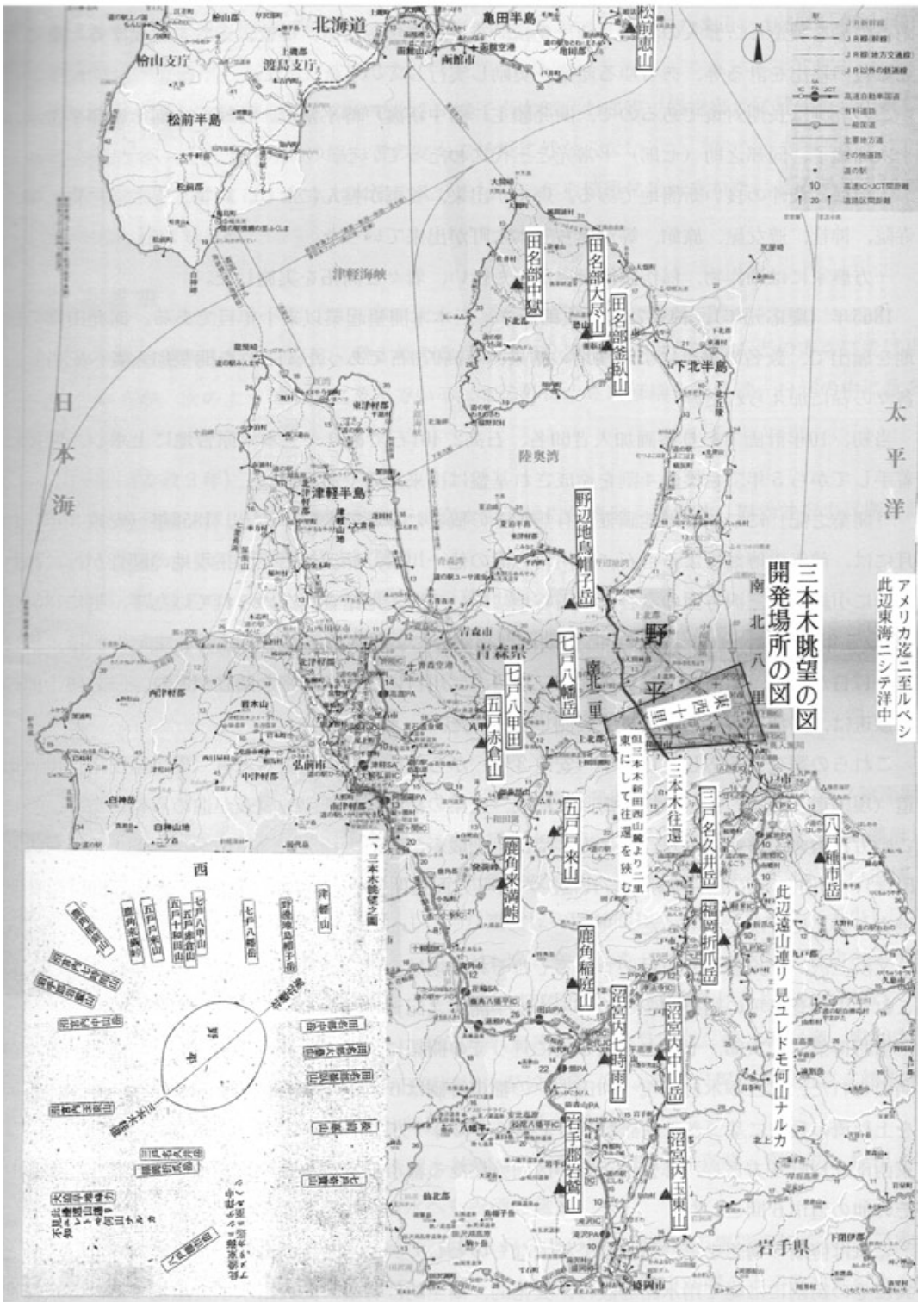

Fig. 2 Map of Sanbonkihara in the northern part of Japan with Tsutō Nitobe's proposal diagram for future development. Source Aomori Kenshi Hensan Kingendaibukai 2007, Aomori Kenshi Shiryohen Kingendai (Aomori Prefecture History, Appendices Modern) 1, Aomori prefecture; released under a Creative Commons Attribution-NonCommercial-NoDerivatives 4.0 International License 
8 Archaic Water: The Role of a Legend in Constructing the Water ...

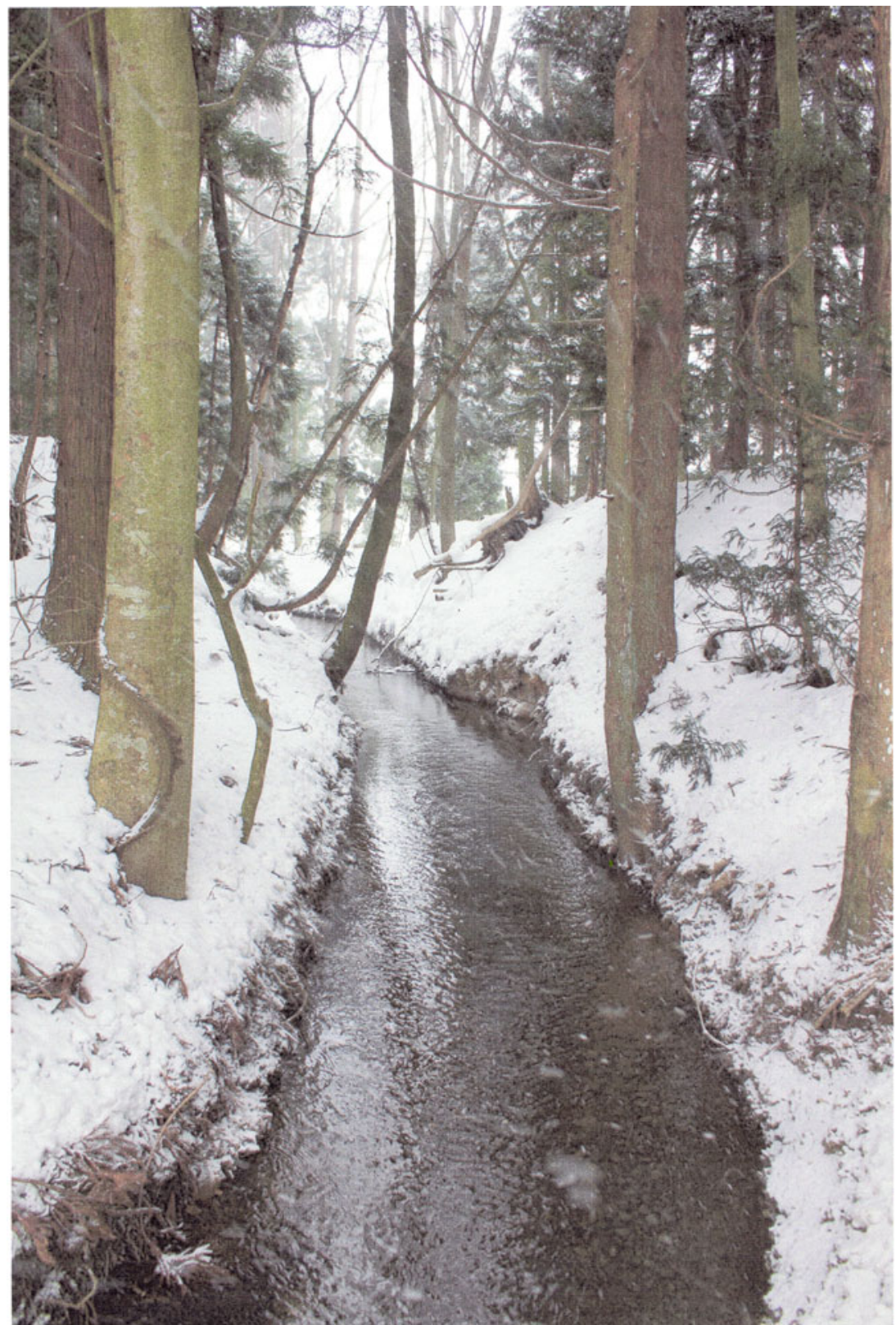

Fig. 3 Old weir utizing natural terrain connecting Oirase River to Fujisaka village. Source Photo taken by the author 2010; released under a Creative Commons Attribution-NonCommercialNoDerivatives 4.0 International License 


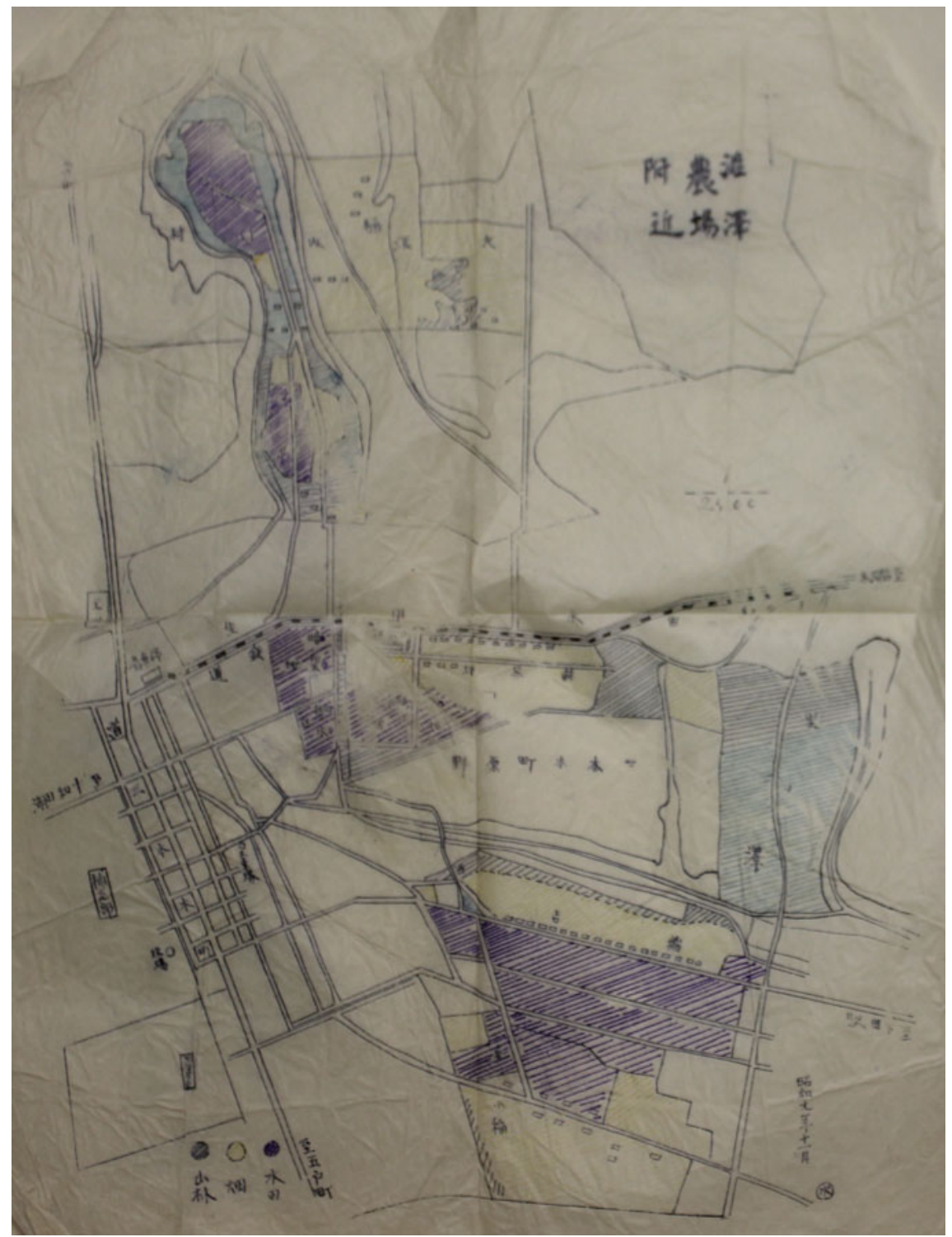

Fig. 4 The purple area indicates Shibusawa farm territories showing how they extended Nitobe's irrigation project to cover the whole area of Inaoi River in the 1930s. Source Shibusawa Bunko archive in Towada City; released under a Creative Commons Attribution-NonCommercialNoDerivatives 4.0 International License 
the Oirase River. The project achieved a dual goal: it secured water for the landscape of Lake Towada and the Oirase Valley while providing water for cultivation and hydroelectric power generation in Sanbonkihara. The project constructed an additional Sanbonki national trunk conduit to uptake water from the Oirase River, allowing the cultivation of large-scale paddy fields. The impact of these works was demonstrable: In 1944, the water supplied by the Oirase River irrigated a record 2500 ha and generated a record $27,000 \mathrm{~kW}$ of electricity.

The second period of intense governmental development in Sanbonkihara followed World War II; indeed, the entire Towada area was eventually slated for national development (Northeast Agricultural Administration Bureau 2016, 2017) to address a postwar crisis in housing and feeding war refugees and veterans. In this effort, two thousand veterans and soldiers were settled on the 4445 ha former Sanbonkihara military site and made farming and state-controlled cultivation their livelihood. In 1948, the government began the Ogawara pond irrigation near the Pacific Ocean as an extension of the Sanbonkihara National Reclamation Project. When this project was completed in 1966, 3376 ha of paddy fields and 5947 ha of crops had been developed, and the waterway was finally extended to seventy-one kilometers to the Pacific Ocean. This massive infrastructure became the foundation of the regional economy. Since then, the maintenance and management of rivers, water supply, and dams have been conducted under prefectural administration in collaboration with LIDs (Fig. 5).

\section{Challenges to the Historiography of the Legend as Heritage in Sanbonkihara}

When we conducted on-site research on water heritage and compared local literature to local history, we discovered that this historical framework did not tell the whole story. It is true that some local and institutional history textbooks, such as Watashitachino Furusato Towadashi (Our homeland Towada City), published by the educational committee of Towada City, described Nitobe's project as a pioneering development. But we discovered many structures from as early as the Edo period, suggesting that Sanbonkihara had already been developed before Nitobe started his work. We also found historical records in private museums and in the museums of neighboring towns that showed that many migrants to the area contributed to local water reclamation on smaller scales over the years. The Tomabechi family from Osaka developed Sanbonkihara's first paddy field in 1673 in an early reclamation project (Aomori Kenritsu Kyodokan 1994; Aomori Kenshi Hensan Kingendaibukai 2007; Inaoi Gawa Tochi Kairyoku 2003). Immigrants from the Uesugi clan introduced fortress construction technology which was then used in irrigation projects by migrants and low class samurais. In 1845, Morita Kiuemon of Shichinohe developed more paddy fields in Sanbonkihara. The Fujita family of Gonohe, originally from Shiga Prefecture, also played a part in developing Sanbonkihara, as well as other villages (Gonohe, Asamizu, Ichikawa, and Osaka). Ema boards or wish plaques with 


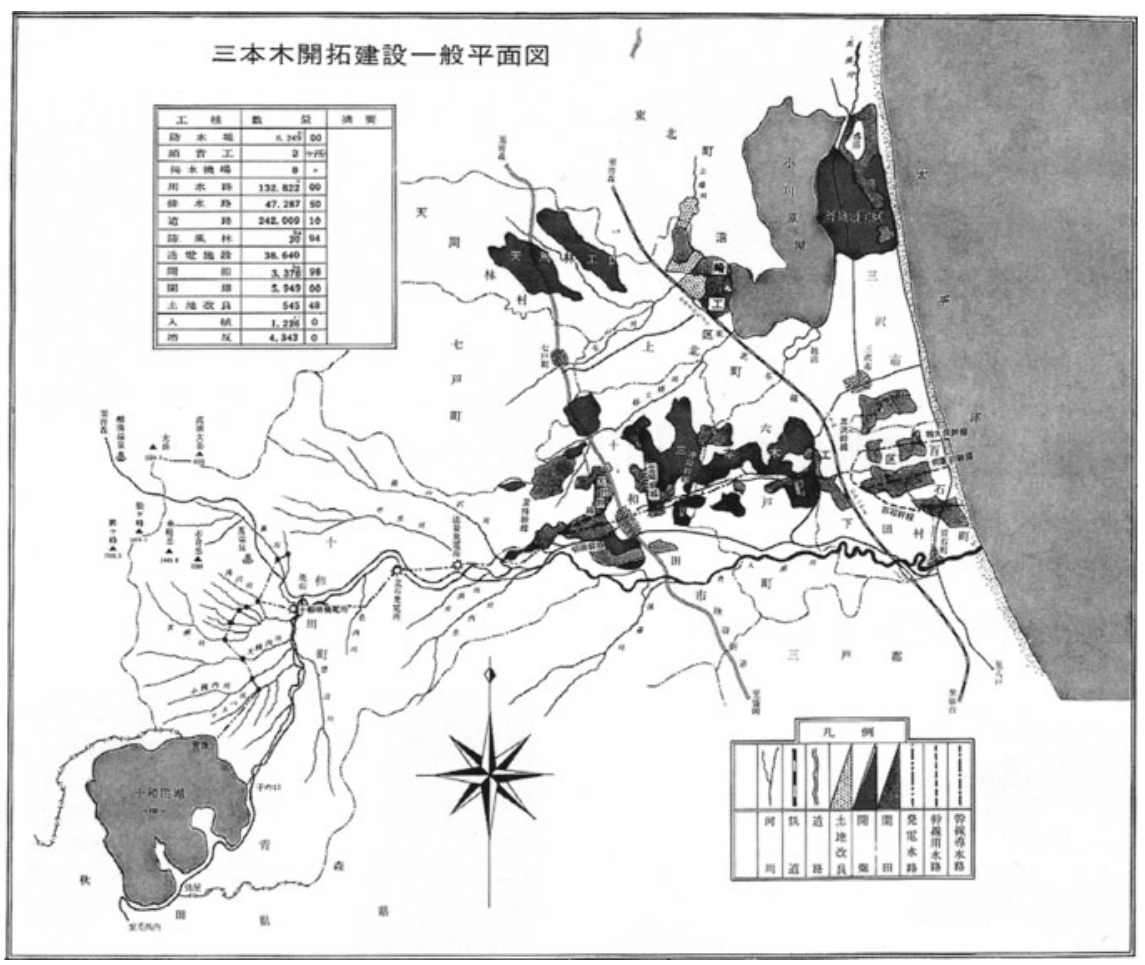

Fig. 5 Development of Sanbonkihara reclamation reaching from Towada Lake to the Pacific Ocean. Source History of Land Improvement Project of Inaoi River, 2003; released under a Creative Commons Attribution-NonCommercial-NoDerivatives 4.0 International License

pictures in local shrines, tell the tragic and heroic stories of those who committed suicide to calm the river god's anger and to protect the area from floods in Edo period (Towada shi kyoiku iinkai 1982; Ministry of Literature 1939; Towada shi kyoiku kenshu senta 1988).

The absence of these peoples' works from local and institutional historical treatments raises questions. Why did authors keep writing that Nitobe was the pioneer and stressing that all later developers were spiritual followers? and why was Sanbonkihara a symbol and a priority of national development until after World War II? (Kahoku Shinpo Newspaper, October 20th, 2017). To answer these questions, we draw on Eric Hobsbawm's idea of historiography, which posits that some historical narratives signal the dominant values of those in power; he argues that such narratives show the range of those who can belong to the nation (Hobsbawm 1990). We found three dynamics essential to our reframing of the legend of Nitobe: first that not only Nitobe but a range of actors developed the reclamation project; second, that national political affairs affected policies on water supply and constructions of national community; and third and last, that cultural events and urban planning bridged tangible and intangible heritage. 


\section{Beyond Nitobe: Other Actors and the Creation and Maintenance of Water Resources}

Although legend attributes the Sanbonikihara reclamation project to Nitobe, in fact, a range of individuals and associations realized it. These actors harbored multiple agendas that evolved over time, held substantially distinct economic ambitions, and worked at different territorial scales which varied according to time. The irrigation project of the Edo period created paddy fields for rice cultivation. In the Meiji period, the Shibusawa farm and military camps introduced new agricultural technology which led to profit from forestry, stock farming, and ranching. Following this success, in the pre-war period, the government established hydroelectric power plants to stabilize water intake with strong pumps and to accelerate the industrialization of Sanbonkihara. Finally, in the postwar period, Yukio Sugimoto, a pupil of Shibusawa, made his ground-breaking economic contributions by establishing a tourism industry in Sanbonkihara (Sugimoto 1981; Inagaki 1998; Sasamoto and Ogasawara 1996; Towada Kanko Newspaper 1957-1968).

In its several different incarnations, the Sanbonkihara reclamation project required a range of niche skills and techniques as well as a very large investment of new technology, capital and labor. Many skilled workers and engineers from outside Towada were involved. Before the Nitobe family, the Uesugi clan and migrants from Shiga had begun to develop Sanbonkihara. After Nitobe, Eiichi Shibusawa and his disciples Mizuno and Sugimoto continued the reclamation work and regional industrial development. Many outsiders came during political upheavals. During the Meiji Restoration, over 17,000 people in the Tonami clan fled from Fukushima to Sanbonkihara as political refugees. Historical textbooks in Sanbonkihara describe how, under the orders of the Meiji Government, Tsutō Nitobe took care of some of them at his farm in 1871, and how they had difficulties getting along with other local residents of the Nanbu clan. Shigeaki Fujita was a descendant of this Tonami clan who later resumed the irrigation project after sixteen years' abandonment. After World War II, many former military personnel and displaced Japanese settled in Sanbonkihara to complete the national irrigation project.

Meanwhile, water resource management frequently switched hands. The irrigation project transitioned from being under a local clan, to a private company and to a government entity. Initially, it was under the Nanbu clan, then the Kyoritsu Reclamation Company, and the Sanbonkihara Reclamation Cooperation. After the Sanbonkihara Reclamation Cooperation dissolved in 1921, the Inaoi River Irrigation Association took over water resource management, and after the war, the Inaoi River Land Improvement Organization assumed leadership. Over time, local people managed and steered these companies, sometimes working in their own interests.

These historical analyses clarify that the actual process of the developing reclamation, the core of intangible heritage, has frequently changed direction, with multiple agents shaping and negotiating changes in the meaning of water (Spirn 1998). 


\section{The Politics of Nitobe's Legend in the Management of Water and Community}

Another way of telling this story is to point out that neither the local community nor the community working on the reclamation project was homogenous. But Sanbonkihara needed a symbolic leader in order to integrate outsiders into Sanbonkihara society, to control tensions in sharing water and land use, and to manage the difficulties of political and industrial modernization overall. Nitobe stood for a social ethos shared by a range of community members that could bridge the government, capitalists, immigrants, and local individuals. These political dynamics shape the story of Nitobe as the legendary founder of Sanbonkihara in books by the Nitobe Memorial archive, local children's textbooks, ministry reports, and the LIDs' books; these narratives exclude other characters for the same political reasons.

Tsuto and Jujiro Nitobe carried out their projects in the transition from the Edo to the Meiji periods. Although political red tape hindered many projects, the Nitobes were highly regarded in the national government, and they played a pivotal role in guaranteeing the legitimacy of the Meiji government in northern Japan. On two occasions in 1877 and 1881, Emperor Meiji visited the Nitobe family's house and honored Tsutō for his accomplishments but for his own interests: to solidify his own historical and ethnic authority, to associate himself with living gods among the people, and to advance his status as a demigod (Osaka 1998). At the same time, this association strengthened the authority of the Nitobes and the power of the local administrative agencies in the region.

In 1884, Emperor Meiji nationalized a large-scale budget for the Sanbonkihara area to support the Kyoritsu Reclamation Company in Nitobe's name. When the Emperor ascended to the throne in 1867, his government had formulated policies to resolve conflicts with the clans he defeated, including state-supported agricultural land development projects (Osaka, Ibid.) Sanbonkihara was the cornerstone of this overall project in the 1880s to make industry the new foundation of the nation: other big projects included Tazawa Lake in Akita and Asaka Hydrophobic in Fukushima (Miyamoto et al. 2002; Northeast Agricultural Administration Bureau 2018). Later, from 1937, as war brought an influx of external laborers for state agricultural cultivation, the legend of Nitobe helped again to inculcate a regional ethics and cultivate a state that diminished discrimination toward immigrants. Thus, as intangible heritage, more than just a local historical story, Nitobe's legend had a lasting and far-reaching impact on the identity of Sanbonkihara.

\section{Cultural Events and Urban Planning Bridging Tangible and Intangible Heritage}

Festivals, statues, and educational activities also all celebrated Nitobe's works as legendary. These cultural events bridged intangible legend and tangible structures. 
In Towada city, Taiso (Archaic) festival is held annually (from 3rd to 5th May) in Taiso Shrine during the season of cherry blossoms, commemorating what is known as Water Flowing Day. People place bronze statues and other memorials to the Nitobe family in the garden of Nitobe archive, tangible heritage for the area. Elementary schools bring children to the Shrine to teach them the legend.

The aura of legend of around the accomplishments of Tsutō Nitobe extends to the urban planning of his son, Jujiro Nitobe. Local historical textbooks celebrate Jujiro's application of Kyoto's urban planning method to Towada in 1860 as unique at the time, particularly his use of the grid system of roads dividing the town into blocks of $1.3 \times 1.3 \mathrm{~km}$; they claim it as the beginning of modern Japanese urban planning (Taiso Kensho kai 1998). They note that Jujiro established the Inari Shrine, Clear Moon Temple, and Rinen Temple out of concern for the people's psychological and spiritual well-being. He designed a canal to bring water from the Inaoi River not only for agricultural purposes but also for domestic use and fire protection in town and designed the city around a canal. He planned a new commercial district in the new town of Inaoi-machi along the Oshu Kaido Road, with two-story shops lining an arcade, and demarcated new districts for different industries (dishware, silk, leather) and even a horse market. At several locations, forests were to be planted to shield against strong seasonal winds.

However, Towada City never actually built the water canal from Inaoi River in its center, and it is unclear how Jujiro's ideas could have contributed to the city's later urban planning. In 1885, well after Jujiro had died in 1867, the Army Battalion Bureau opened a new training center and expanded Jujiro's original grid system to form the current city area of about $4 \mathrm{~km}^{2}$, sandwiched by Inaoi River and Oirase River. In the updated grid, Taiso Shrine (1965, much later than the planning described here) is clearly separated from the surrounding town by a torii gate with a designated approach on a strong spatial axis, which suggests its intentional alienation even from the Army's revision of Jujiro's original idea. Despite the legend, then, Towada City was not developed according to Jujiro's planning. It was largely influenced by the pre and post WWII planning, which followed the planning of Sapporo city (Towada shi kyoiku kenshu senta 1981) (Fig. 6).

\section{Transformation of the Territory and Values of Heritage}

The gaps between legend of Jujiro Nitobe and the actual landscape of Towada city also echo the shifts in the historical relationship between the legend of the elder Nitobe and the landscape. The clearest evidence of this shift is that the area named Sanbonkihara itself changed through history. After the formation of Aomori and Iwate prefecture in 1871, the city territory changed from Sanbonki-cho to Sanbonki city and finally Towada city, with various city mergers extending Nitobe's legendary status geographically. What "Sanbonkihara" means in the legend has also expanded from the actual project site: adding Tonami clan's new settlement after 1869 in the nearby Ninohe and Sannohe area, Shibusawa farm's wide ranch area along Inaoi 


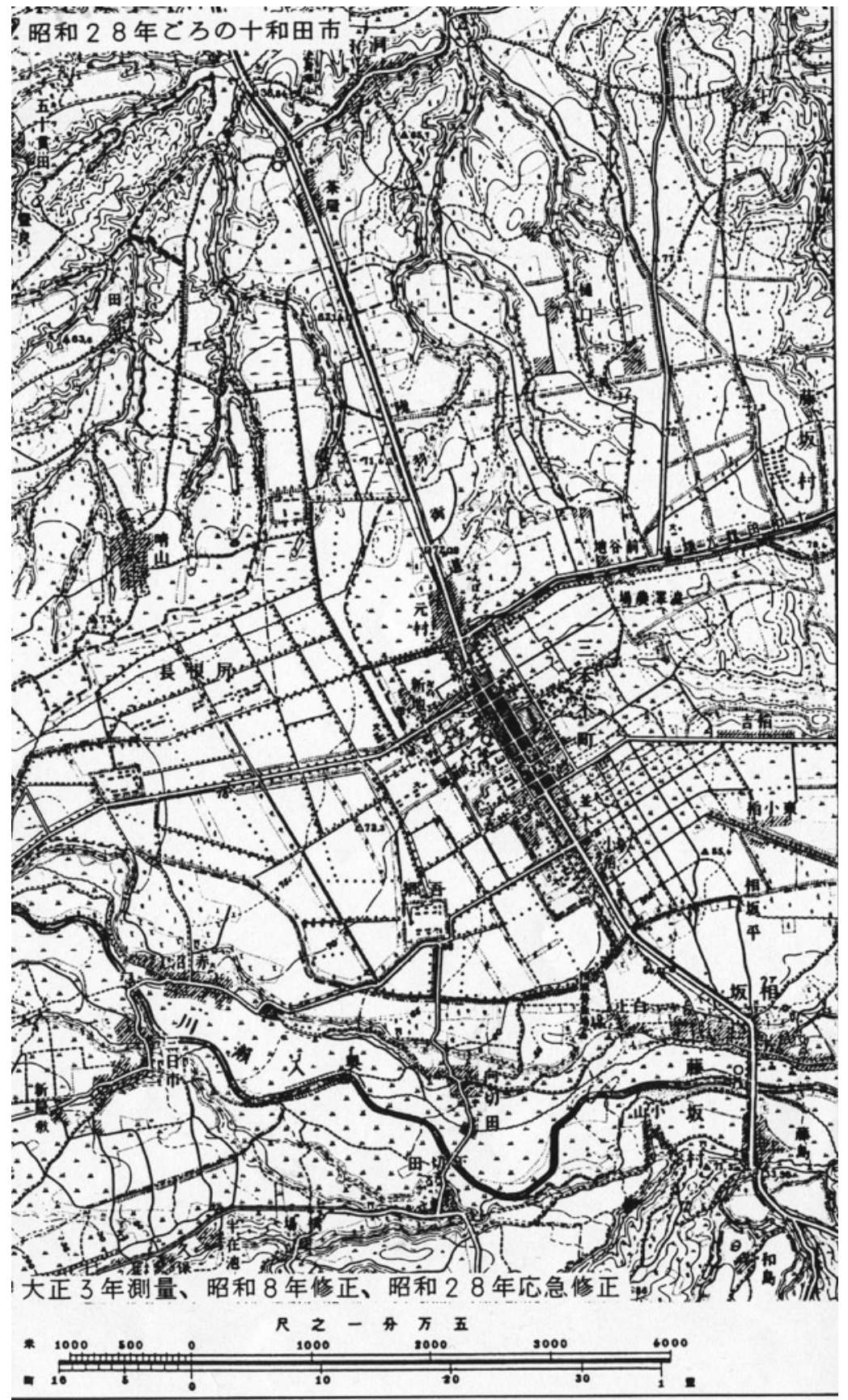

Fig. 6 Whole area map of Towada city downtown area showing post WWII grid roads extentions in the former Army Battalion area. Source Towada shi kyoiku kenshu senta; released under a Creative Commons Attribution-NonCommercial-NoDerivatives 4.0 International License 
River, the national irrigation projects connected to Towada and Ogawara lakes, and Sugimoto's tourism from Towada to the Misawa area (Aomori Kenshi Hensan Kingendaibukai 2007). In each stage, the image of the landscape of Sanbonkihara in Nitobe's legend is significantly different; paddy field, ranch field, broader farming land reaching to the Pacific Ocean, and natural valley with deep woods and Towada lake (Fig. 7).

Another significant shift is apparent in the aesthetic value of water in each stage of the story. The early texts of the legend of Nitobe did not mention the beauty of the landscape. Then, in the Edo period, Japan celebrated the beauty of the west side of Towada Lake (in Akita prefecture) as a kind of heritage, and 1930s state projects and 1950s works by Sugimoto recognized the beauty and cultural values of the length and landscape of the rivers from Towada Lake to Sanbonkihara (Okubo et al. 1993). In building the Towada Science Museum in 1953, Ogawara Lake Ethnic Museum in 1958, and Saigyodo park in 1980, Sugimoto combined local folklore with the landscape, bringing together intangible and tangible heritage. Claiming Nitobe and Shibusawa as his spiritual predecessors, Sugimoto rode the waves of capitalist success and began a nationwide tourism project between the Oirase River and Tokyo in 1967 (Nakazono 2012).

\section{Conclusion}

This chapter reframes the relationship between water and people in the Sanbonkihara region and the contribution of Nitobe's legend to local society to include the effects of the ever-evolving interactions between people, space, and society in and after Nitobe's time. The value of water and the landscape was not a simple outcome of Nitobe's project but developed in the historical process of agricultural expansion, river conservation, and redevelopment, and in the historical process of spatializing and formalizing the legend. Political, economic, and social restructuring kept creating a new sense of community and new interrelationships between tangible and intangible heritage (Tuan 1993).

Though the legend of Nitobe faded with time, its spirit remains in the natural and everyday spaces of Sanbonkihara, continuing to evolve with the people who visit or live there (Kahoku Shinpo Newspaper 2017). In this period of declining agriculture and traditional social ethos in Japan, it is necessary to re-establish water not merely as a natural resource or as an asset of agricultural landowners but as the whole community's historical, cultural and social inheritance; heritage, with which diverse people have to actively engage and cultivate for their and future generations' survival. 


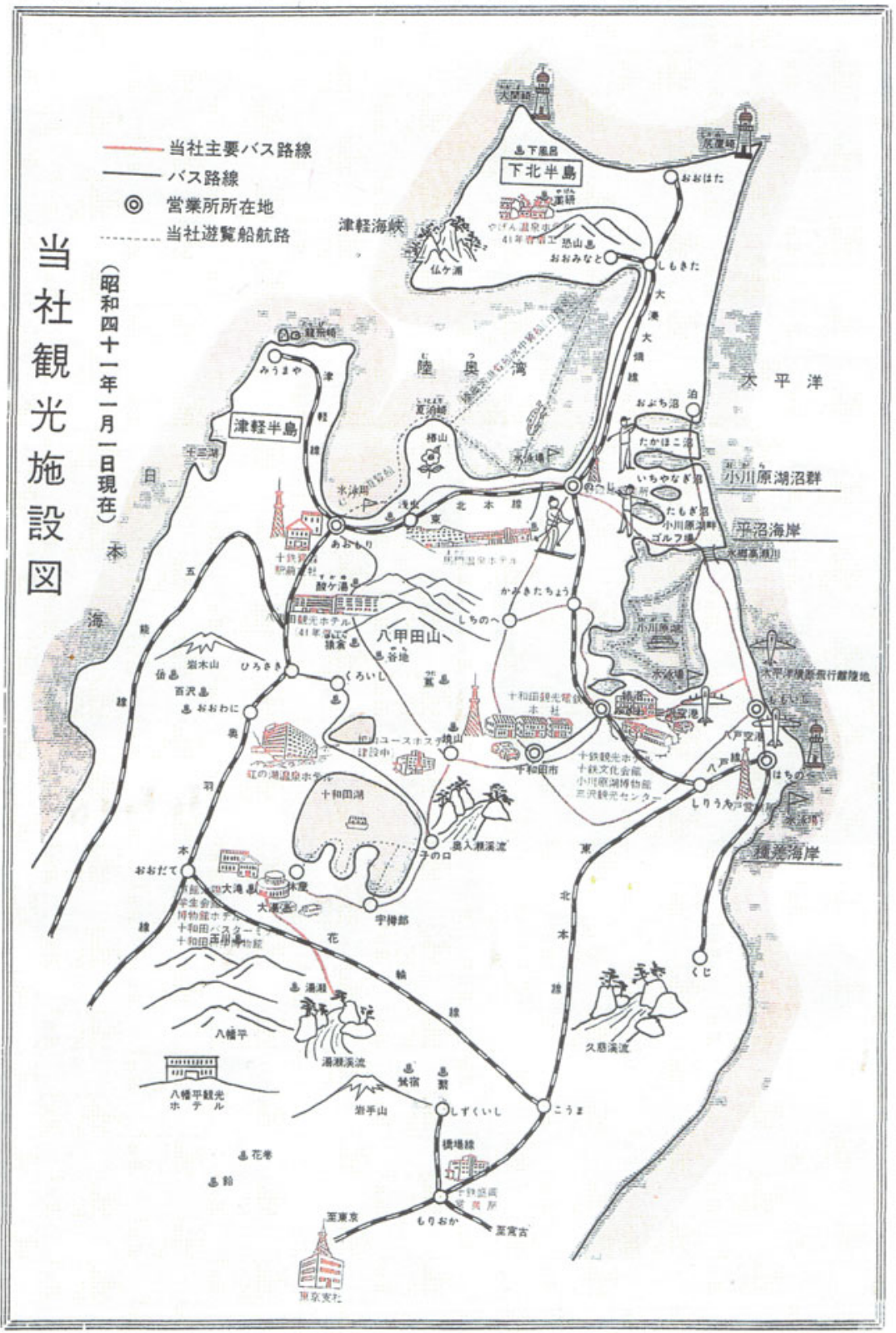

Fig. 7 Expansions of Sugimoto's tourism industry from Sanbonkihara to Tokyo. Source newspaper Towada Kanko, published in 1966; released under a Creative Commons AttributionNonCommercial-NoDerivatives 4.0 International License 
Acknowledgements This study was made possible by the material and support of Towada city, Shibusawa Bunko, Aomori Prefecture office, Inaoi Tochi Kairyoku, Towada Kanko, and Nitobe Kinenkan. The original research started with funding from the Toyota Foundation and later developed through support from the Ministry of Literature. The project evolved to its current theme thanks to the advices by Professor Masamitsu Ogiwara and Mr. Mamoru Okubo, and to the conference on Water and Heritage for the Future organized by ICOMOS, the Center for Global Heritage and Development (CGHD), and Delft University of Technology. I appreciate the support of Professor Carola Hein for inviting me to the conference and helping edit my text.

\section{References}

Anderson B (1983) Imagined communities: reflections on the origin and spread of nationalism. Verso, London

Aomori Kenritsu Kyodokan (1994) Inaoi gawa to Dobuchi seki. Aomori, Aomori ken

Aomori Kenshi Hensan Kingendaibukai (2007) Aomori Kenshi Kingendai Shiryohen (Aomori Prefecture History, Modern, Appendices) 1, Aomori Prefecture

Aomori Kenshi Hensan Kingendaibukai (2015) Aomori kenshi shiryohen, Kinsei (Aomori Prefecture History, Modern, Appendices) 6, Aomori Prefecture

Bruner JS (2003) Making stories: law, literature, life. Harvard University Press, Cambridge

Komori H (1996) Nogyo suiri to nihon gata shakai (agricultural water system and Japanese society). In: Shokei Ronso, no 45, pp 1-19

Higuchi T (1975) Keikan no Kozo: Landscape to shiteno Nihon no Kukan (Structure of landscape: Japanese space as landscape). Gihodo Shuppan, Tokyo

Hobsbawm E (1990) Nations and nationalism since 1780: programme, myth, reality. Cambridge University Press, Cambridge

Inagaki M (1998) Sugimoto Yukio Monogatari. Ryoko Yomiuri Shuppann, Tokyo

Inaoi Gawa Tochi Kairyoku (2003) Inaoi Gawa Tochi kairyokushi (History of Inaoi River LIDS). Inaoi Gawa Tochi Kairyoku, Sanbonkihara

Ishida Y (2004) Nihon Kingendai Toshikeikaku notenkai (Transformation of the modern and contemporary Japanese Urban Planning)1868-2003. Jichitai Kenkyusha, Tokyo

Ishii M, Nagaoka A, Harada T (1996) Kokudo Riyo no henyo to chiiki shakai (Transformation of the use of National Land and local society). Daimyodo Hakko, Tokyo

Akimoto H (2004) Wagakuni Kindai niokeru Nogyo suiri chitsujo no Saikento (Reexamination of the agricultural water right order in the modernization of Japan). Keizai Ronshu 29(2):1-11

Kahoku Shinpo Newspaper (2017) Oct. 20th, Kahoku Shinpo, Sendai

Kahoku Shinpo Newspaper (2017) Nitobe memorial archive was ordered to close its building for seismic problem by Towada city and is appealing to a court. http://www.kahoku.co.jp/ tohokunews/201710/20171021_21036.html. Accessed 2 Jan 2018

Kawahara I (2001) Chikyu Kankyo to Tokyo (Global environment and Tokyo). Chikuma shobo, Tokyo

Kide I (ed) (1984) Suiri no Shakai kozo(Social structure of water management). Kokusai rengo daigaku press, Tokyo

Kimura S (2010) Nihon Nogyo shi. Yoshikawa Kobundo, Tokyo, pp 256-320

Ministry of Agriculture, Forestry and Fisheries production (2017) Tochikairyo ku, Tochikairyo Jigyodantai rengokai ni tsuite (LIDs and association of LIDs). file:///Users/Izumi/Desktop/農林 水産省:土地改良区・土地改良事業団体連合会について.html. Accessed 10 Dec 2017 
Ministry of Agriculture, Forestry and Fisheries. Sanbonkihara Daichi wo Kaitakushita Nitobe Tsutō. http://www.maff.go.jp/j/nousin/sekkei/museum/m_izin/aomori/. Accessed 2 Jan 2018

Ministry of Literature (1939) Tohoku Dokuhon (Reading about the Northern part of Japan), Gekan, Towada city, 1-3, 42-45

Miyazaki J (2009) Kanko suiriken no ruikei to sono koryoku(typology of customary water right law and its effectivity). Mizu shigen, kankyo kenkyu 22:1-12

Miyamoto T et al (2002) Aomoriken niokeru Shizoku jusan to tsugaru ai sangyoka henokokoromi (The Industrialization and education of Samurai class and the creation of dying industry in Aomori). In: Review of the researches in educational department of Hirosaki University, vol 87, pp 89-98

Mizoguchi S (1948) Uton, Suiri Shidan (Rainy village, history of water management). Yukei sha, Tokyo

Mizuno N (1961) Taishi wo tsuide. Sanbonkihara Kaihatsu Kenkyukai, Towada city

Nakazono H (2012) Totestu ga hashitta jidai. In: Toou nippou, 2.14-25

Nitobe I (1898) Nogyo Honron (Principles of agriculture). Mokabo, Tokyo

Northeast Agricultural Administration Bureau. Aomoriken, Towadakoshuhen, Sanbonkihara Daichimonogatari (Aomori prefecture, Area of Towada lake, Sanbonkihara Plateau story). http:// www.maff.go.jp/tohoku/nouson/seibi/rekisi/6story01.html. Accessed 2 Jan 2018

Northeast Agricultural Administration Bureau (2016) Kokuei Kangai Haisui Jigyo: Ousakagawa sagan chiku (National Irrigation and wast-water project: Ousaka river left bank area

Northeast Agricultural Administration Bureau (2017) Suido no Ishizue (Foundation of water and earth). file:///Users/Izumi/Desktop/陸奥の先進地\%20一福島県\%20国営会津北部農栄水 利事業\%20一水土の礎.html. Accessed 20 August 2017

Northeast Agricultural Administration Bureau (2018) The histories of these three projects. http:// www.maff.go.jp/tohoku/nouson/seibi/rekisi/6story01.html. Accessed 2 Jan 2018

Ogasawara K (1996) Shibusawa noujo to sanbonkihara no yoake. Seikoen shuppann, Towada city

Ogasawara Y (1994) Shibusawa Nojo no Kaihatsu to Keiei, Towada city

Okuda S (2010) Nogyo Suirichitsujo to Suiriken no arikata (Order of water distribution and the way of water right control). In: Aoyama Homu Kenkyu ronshu (Aoyama Legal research collection), Aoyama Gakuin publication, no 3, vol 1, pp 107-131

Okubo H et al. (1993) Towadako, Oirasegawa no Fuchihozennto kaihatsu tono chosei (Study on the Planning Methods for Coordination between the keeping scenic beauty place and the development of water resources in Towada Lake and Oirase River Basin). In: Nodo shi, no 61, vol 10, pp 927-932

Osaka H (1998) Daijo kanki Chiho Junko no Kisoteki kenkyu (Basic examination of the rural tour by Meiji Emperor in his early ruling period). In: Hosei Shigaku. Tokyo, Hosei Shigakkai, no 50. March, pp 62-72

Sanbonkihara Kaihatsu Kenkyukai (1967) Kaitaku no Oni, Towada city

Sasamoto K, Ogasawara K (1996) Chosen, Tokyo, Jitsugyo no Nihon sha. Towada Kanko Newspaper, Towada shi, 1957-1968

Shiga S (1995) Nihon Fukeiron. Iwanami Bunko, Iwanami Shoten, Tokyo

Shobayashi M, Okajima M (2017) Kikan suiri sisetuno jizokutekina koshinnotameno aratana seidoteki wakugumi (New Legal framework to sustainable renewal of the main irrigation facility). In: Nogyo Noson Kogakkaishi (Agriculture and agricultural area engineering academy research review), vol 85, no 9, pp 21-27

Soja E (2003) Writing the city spatially. In: City: analysis of urban trends, culture, theory, policy, action, vol 7, no 3, Routledge, London, pp 269-281 (13), November 2003

Spirn AW (1998) The literature of landscape and survival and imagination: reading and telling the meaning of landscape. In: The language of landscape. Yale University Press, New Haven, pp $27-46,47-81$ 
Sugimoto Y (1981) Shibusawa Keizo sensei ni tsukaete

Taiso Kensho kai (1998) Towadashi, Sanbonkihara Kaitaku to Nitobe sandai no Rekishi gaidobukku (Guide book about history of the development of Sanbonkihara in Towada city and the three generation of Nitobe). Nitobe Kinenkan, Towada city

Towada shi kyoiku kenshu senta (1981) Chugakko shakaika fukudokuhon Wagakyodo Towada shi, 78, Aomori

Towada shi kyoiku iinkai (1982) Watashitachino Furusato Towadashi (Our home land Towada city), Towada city

Towada shi kyoiku kenshu senta (1988) Kyoudogakushuu shiryou, zokuzoku medemiru towadashi no daichi (Material for the program of learning homeland and additional material of visual survey of the area of Towada city). In: Sanbonkihara wo hiraku(Reclaim Sanbonkihara plateau), Towada city

Towada Kanko News paper (1957) 8.1-1968, 10.15, Towada Kanko Dentetsu

Toyama K (1993) Nihon no Kome: Kanko to Bunka wa kakutsukurareta (Japanese Rice: this is the way how tourism and culture have been developed). Tokyo, Chuko Shinsho, pp 28, 122, 154-159

Tuan Y-F (1993) Space and place, Chikuma Gakugei Bunko, tr. hiroshi yamagata, pp 265-282

Waterson E, Smith L (2010) The recognition and misrecognition of community heritage. Int J Heritage Stud 16:4-15

Watsuji T (1979) Fudo: Ningengakuteki kosatsu (Climate: Examination as humanistic study). Iwanami Bunko (Originally it was published in 1938), Tokyo

Wigen K (1995) The making of a Japanese periphery, 1750-1920. University of California Press, pp 1-21, 70-79

Yamasaki K (1996) Kanto chiho no mizu shigenno hippakuto sonohaikei(Study of the critical shortage of the water resource in Kanto region and its background). In: Ishii M, Nagaoka A, Harada T (eds) Kokudoriyouno henyo to chiikishakai (Transformation of the Use of National Land and Local Society), 26. Daimyodo Hakko, Tokyo

Yanagita K (1997) Jidai to Nosei (Contemporary Society and Agricultural policies), vol 2, Anthology of Yanagita's Works, Tokyo, Chikuma shobo (originally published in 1911)

Izumi Kuroishi is professor of the School of Cultural and Creative Studies of Aoyama Gakuin University, Japan. Her recent publications include Constructing the Colonized Land (Ashgate 2014) and "Urban Survey and Planning in Twentieth-Century Japan" (JUH, 2016). She currently works on disaster relocation and social resilience after the 2011 tsunami and on domestic space and house planning in wartime Japan.

Open Access This chapter is licensed under the terms of the Creative Commons AttributionNonCommercial-NoDerivatives 4.0 International License (http://creativecommons.org/licenses/bync-nd/4.0/), which permits any noncommercial use, sharing, distribution and reproduction in any medium or format, as long as you give appropriate credit to the original author(s) and the source, provide a link to the Creative Commons license and indicate if you modified the licensed material. You do not have permission under this license to share adapted material derived from this chapter or parts of it.

The images or other third party material in this chapter are included in the chapter's Creative Commons license, unless indicated otherwise in a credit line to the material. If material is not included in the chapter's Creative Commons license and your intended use is not permitted by statutory regulation or exceeds the permitted use, you will need to obtain permission directly from the copyright holder.

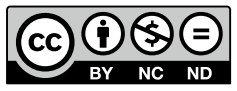

